\title{
STEEP INCREASES IN BIOMASS DEMAND: THE POSSIBILITIES OF SHORT ROTATION COPPICE (SRC) AGRO-FORESTRY
}

\section{Laurencas RASLAVIČIUS ${ }^{a}$, Brian AZZOPARDI ${ }^{\mathrm{b}, c, \mathrm{~d}}$, Aleksandr K. KOPEYKA ${ }^{\mathrm{e}}$, Jonas ŠAPARAUSKAS ${ }^{f}$}

${ }^{a}$ Department of Transport Engineering, Kaunas University of Technology, Studentu g. 56, 51424 Kaunas, Lithuania

${ }^{\mathrm{b}}$ Institute of Electrical and Electronics Engineering, Malta College of Arts, Science and Technology (MCAST), MCAST Main Campus, Triq Kordin, Paola PLA 9032, Malta

'Department of Mechanical Engineering and Mathematical Sciences, Faculty of Technology,

Design and Environment, Oxford Brookes University, Wheatley Campus, Oxford, United Kingdom

${ }^{\mathrm{d}}$ Brian Azzopardi and Associates Consulting Firm, Birkirkara, Malta

${ }^{e}$ Odessa I. I. Mechnikov National University, Dvoryanskaya str. 2, 65026 Odessa, Ukraine

${ }_{\mathrm{f}}^{\mathrm{f}}$ epartment of Construction Technology and Management, Vilnius Gediminas Technical University,

Sauletekio al. 11, 10223 Vilnius, Lithuania

Received 11 September 2014; accepted 11 January 2015

\begin{abstract}
At current usage levels, short rotation coppice (SRC) biomass could be considered as an untapped resource. There is a worldwide interest to extend its sustainable production significantly in a decade to come. However, the cultivation of energy crops is very site-specific and the exploitation of SRC biomass is a relatively new trend in biomass application for heat and power production with little information on its cultivation patterns and appropriate combustion technologies. In fact, documented biomass conversion technologies' impacts in the energy sector and their commercialisation are limited. This paper aims to present a summary of technical characteristics for different biomass conversion technologies. These characteristics are not necessarily unique to all types and possible modifications of the biomass conversion technologies applied for many countries. However, the lack of technical knowledge have created situations that were previously impossible to be solved without the aid of numerous research and development activities. The developers did not capture all of the economic benefits that the technology provides which would help to reach its technical accomplishment and commercial execution.
\end{abstract}

Keywords: biofuel production costs, biofuel supply and demand, biomass combustion technologies, short rotation coppice (SRC) biomass, willow plantations.

JEL Classification: Q16, Q21, Q23, Q41, Q42, Q47, Q55.

Corresponding author Laurencas Raslavičius

E-mail: laurencas.raslavicius@ktu.lt 


\section{Introduction}

Plant-derived biomass is considered as an important source of alternative energy. Wood-based biomass, including energy crops, is expected to be a major contributor, achieving ambitious goals for renewable energy (RE) in many countries (Berndes et al. 2008; Ravindranatha, Hall 1996; Thrän et al. 2010). There is little doubt that world countries need to reduce their dependency on fossil fuels in order to provide sustainable sources of energy for the future and to alleviate global climate change (Djomo et al. 2011; Raslavičius et al. 2013). However, future increases in biofuels must come from advanced biofuels, everything else will be unsustainable (Directive 2009/28/EC 2012). The so called "First Generation" energy crops (wheat, potatoes, maize, barley, sugar beet/cane, oil rape, sunflower) may not be seen as a solution anymore because of the competition for arable land between food and biofuel feedstock. There are also doubts over whether deriving bio-energy from food crops containing sugars and starches does indeed result in a reduction in Greenhouse Gas (GHG) emissions (Yin et al. 2008). To give high yields, dedicated crops-to-biomass production systems for energy purposes require high inputs of nitrogen fertiliser to promote plant growth and improve product quality, which requires a lot of energy in its manufacturing process (Siemons 2002). This means that, on balance, the emission-reduction of GHG and energy saving achieved are minimal or, in some cases, even negative (Harris et al. 2011).

"Second generation" (non-food) energy crops such as willow, poplar, and others have several distinct advantages in sustainability-driven management over food-crops (Valentine et al. 2012). Life Cycle Assessments (LCAs) for SRC-derived bio-energy and biofuel show higher Green-House Gas (GHG) reductions and energy savings than those of the "First generation" (Cherubini, Strømman 2011; Djomo et al. 2011). This is because dedicated energy crops recycle the majority of their nutrients during growth, reducing the amounts of nitrogen fertilizer required (Drewer et al. 2012). According to Goglio and Owende (2009), the key GHG emission compatibility factor was the type of combustion technology, which had up to $36.4 \%$ variation in net energy production, and $96.4 \%$ reduction in $\mathrm{CO}_{2}$ emission. The choice of fertilizer type, application technique and drying technology were very important factors as well (Goglio, Owende 2009).

There is no annual cycle of agricultural activities and the SRC crops are fast growing with the potential to use small amounts of pesticides and nutrients for large gains in biomass yield. Some concerns arise from energy crop willow roots causing damage if planted near drains, the use of land previously used for food production, the clearing-cutting of the forest stands to make way for these crops, or the fact that SRC plants could possibly have a negative impact if grown extensively as a monoculture because of the transformation of land tenure and the impoverishment of resources (Baltodano 2000). In fact, when SRC crops plants are used to provide feedstock for heat and/or electricity, $\mathrm{CO}_{2}$ produced by a process is exactly balanced by the amount of $\mathrm{CO}_{2}$ either offset or sequestered by that process.

Current energy supply rates have failed to meet the ever-increasing demands. Many developing countries have a great potential for expanding local biofuel market and reap the derivative effects in relation to energy and environment on faster growing biomass like short rotation forestry (SRF) and SRC (Raslavičius et al. 2011, 2013; Raslavičius 2012). Driven by 
the rising population, expanding economy and a quest for improved quality of life, energy usage in these countries is expected to rise at an alarming rate (Kamath 2012). Energy forestry and energy crops lessen the environmental impact connected to energy production and consumption and contribute to meeting country's international obligations for the discharge of GHG, sustainability and biodiversity.

The lack of detailed projections for SRC bio-energy results from very limited production experience. Recently, a pilot-scale project has been implemented in Kazlų Rūda, Lithuania. It provides useful information on procedures, facilities, manpower, energy and used materials, which allows a thorough assessment.

In this paper, we present the current findings using primary unpublished data and observations from the biomass firing pilot boiler-house using different kinds of solid biomass as a fuel. The paper also details cultivation and harvesting of SRC crops experience gathered in Lithuania, rationality of production with an in-depth look at industrial combustion systems, including their types and applications (Raslavičius et al. 2011).

This paper is structured as follows. In Section 1, the methods for collected data analysis are described, followed in Section 2 by original analysis of experience acquired by establishing SRC plantations gathered by means of structured interviews. Then, in Section 3, an assessment of biofuel combustion technologies combining detailed experience narration on the pilot project site experience and evaluation of request for proposal (RFP) responses is provided. Finally, the main conclusions are presented in the last Section.

\section{Collected data analysis}

The primary data on SRC cultivation were collected through the approach that involved the use of structured questionnaires (see Appendix A), focus group discussions at the household and community levels, and face-to-face (in-person) interviews. Local visits were held on April-June 2014. Obtained data constituted an input for further description of SRC biomass potential for energy. To verify study analysis the information from Ministry of Environment of the Republic of Lithuania and local companies was used.

The logic of "technology designs application" was based on research which raised the important question about how far is a technology design applicable to usage. Different factors were taken into account about the lesson-learned, demonstrating impacts, data availability, and skills, about how to ensure efficient use of wood biomass and, in initial development stage, how to involve stakeholders, among other factors. Part of the research have been based on SRC biomass conversion data gathered from publications, relevant books, journals, reports, and case studies from Lithuania and elsewhere in the developing world which provided the theoretical basis for designing the field instruments and analysis of the data.

Evaluation of request for proposal (RFP) responses involved the collaborative efforts of a research team. The evaluation team has been made up of scientists, co-authors as well as Lithuanian and Ukrainian experts, with varied talents and expertise to assure impartiality. Lithuanian suppliers, as well as suppliers from other countries submitted proposals in response to RFP launched by KTU. It should be emphasised that some of the biofuel combustion technology designs identified that gasification and co-firing have not previously been applied in Lithuania. Hence, the report is for the most part conceptual analytic and methodological. 
Questions for most evaluations (Appendix A) were set by Lithuanian policy makers and commissioners as well as scientists who incorporated some parts of methodology for country studies from their previous works (Raslavičius et al. 2011). Different parts of evaluation methodology are following the recommendations of Stilger (2012), Soroudi and Amraee (2013), Otter (2007), Kim et al. (2011), Štreimikienè (2013), Zavadskas et al. (2014a, 2014b), and Grzybek (2010).

\section{The prospects of agro-forestry in Lithuania}

\subsection{Solid biofuel consumption scenario, economics, and the role of the SRC plantations}

According to LEKA (2013), local fuel resources are expected to be used to meet the estimated demand for 2020 to 2025 wood-based biofuel:

- Biofuel from SRC plantations range from 40 to 400 thousand cubic meters, depending on sustainability of support scheme to producers of this kind of biofuel, under the condition that respectively, 2.4 to 22.1 thousand hectares of land are allocated to these plantations.

- All industrial wood waste, 1.6 million cubic meters, are used based on the estimated scopes of production by wood and wood product manufacturing industry and growing volumes of wood processing.

- All fuel wood resulting from wood cutting activity, about 1.8 million cubic meters, are used. This is based on the estimation that approximately one million cubic meters of this wood is used for production of wood panels.

- Almost all wood remaining after grey alder site cutting is collected for biofuel production, about 600 thousand cubic meters.

- Wood waste resulting from cutting of almost 600 thousand cubic meters of forest wood, approximately one third of all wood waste resulting from forest cutting activity).

- About 600 thousand cubic meters of wood resulting from maintenance of green zones, orchards, roadsides, areas around ditches, and certain amount of reclaimed wood.

- 40 to 170 thousand cubic meters of wood resulting from cultivation of forest saplings, depending on availability of support scheme for producers of this kind of solid biofuel.

Same as for any merchandise, solid biofuel is subject to laws of supply and demand, namely, the higher the demand, that is consumption, the higher the price. Two selected scenarios of wood biofuel consumption were calculated by LEKA for the year 2025: "low" (730 thous. toe) and "high" (1484.1 thous. toe). In the context of increasing demand for biofuel, supply is provided from more expensive sources, for example, currently SRC (LEKA 2013). In case of low biofuel demand, industrial wood waste and fuel wood are enough to produce the required amounts of solid biofuel. These are the biomass resources that are naturally generated in the form of by-products, irrespective of the biofuel demand (LEKA 2013). Increasing demand for wood biomass calls for additional resources, for example, woody cutting waste, hay, grey alder wood, etc (LEKA 2013). With the demand increasing even further, more expensive resources are used. These require respective infrastructure and accumulation of wood waste 
that results from maintenance of green zones, orchards, roadsides, areas around ditches, collection of reclaimed wood waste (LEKA 2013). As the demand continues to grow, use of wood resulting from cultivation of forest saplings, SRC plantations, etc. becomes economically reasonable (LEKA 2013). It is also important to account for growing fuel transportation costs (see Table 1) due to longer transportation distances from the fuel production site to its consumer as the result of the growing demand for local fuel (LEKA 2013).

Table 1. Evaluation of wood biofuel production cost

\begin{tabular}{|c|c|c|c|c|c|c|c|c|}
\hline & 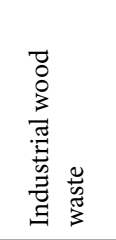 & 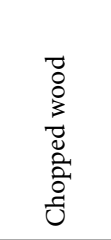 & 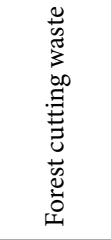 & 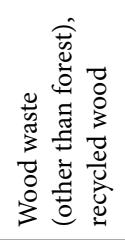 & 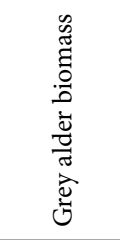 & 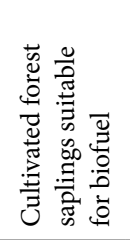 & 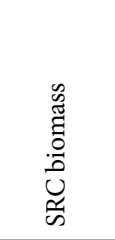 & 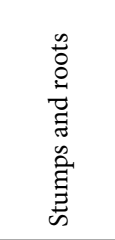 \\
\hline $\begin{array}{l}\text { Minimum } \\
\text { theoretical price of } \\
\text { the raw material }\end{array}$ & $\begin{array}{c}>0 \\
\mathrm{EUR} / \mathrm{m}^{3}\end{array}$ & $\begin{array}{c}>5.8 \\
\mathrm{EUR} / \mathrm{m}^{3}\end{array}$ & $\begin{array}{c}>1.5 \\
\mathrm{EUR} / \mathrm{m}^{3}\end{array}$ & $\begin{array}{c}>1.5 \\
\mathrm{EUR} / \mathrm{m}^{3}\end{array}$ & $\begin{array}{c}>5.8 \\
\mathrm{EUR} / \mathrm{m}^{3}\end{array}$ & $\begin{array}{c}>1.5 \\
\text { EUR/m } / \mathrm{m}^{3}\end{array}$ & $\begin{array}{c}>5.8 \\
\mathrm{EUR} / \mathrm{m}^{3}\end{array}$ & $\begin{array}{c}>5.8 \\
\mathrm{EUR} / \mathrm{m}^{3}\end{array}$ \\
\hline $\begin{array}{l}\text { Biofuel production } \\
\text { cost price }\end{array}$ & $\begin{array}{c}0-7.3 \\
\mathrm{EUR} / \mathrm{m}^{3}\end{array}$ & $\begin{array}{c}4.3-7.3 \\
\mathrm{EUR} / \mathrm{m}^{3}\end{array}$ & $\begin{array}{l}12-24.4 \\
\mathrm{EUR} / \mathrm{m}^{3}\end{array}$ & $\begin{array}{c}13.9-34.4 \\
\mathrm{EUR} / \mathrm{m}^{3}\end{array}$ & $\begin{array}{c}11.8-15.8 \\
\mathrm{EUR} / \mathrm{m}^{3}\end{array}$ & $\begin{array}{c}16.3-37.6 \\
\mathrm{EUR} / \mathrm{m}^{3}\end{array}$ & $\begin{array}{l}19.9-40 \\
\mathrm{EUR} / \mathrm{m}^{3}\end{array}$ & $\begin{array}{c}29.3-36.8 \\
\mathrm{EUR} / \mathrm{m}^{3}\end{array}$ \\
\hline \multicolumn{9}{|c|}{ Cost price components: } \\
\hline Investment & $35 \%$ & $35 \%$ & $20.4 \%$ & $30 \%$ & $18.2 \%$ & $12.8 \%$ & $30.4 \%$ & $28.5 \%$ \\
\hline Interest & $5 \%$ & $5 \%$ & $2.9 \%$ & $5 \%$ & $2.5 \%$ & $1.7 \%$ & $24.6 \%$ & $4.2 \%$ \\
\hline Fuel and oil & $30 \%$ & $30 \%$ & $30.1 \%$ & $17 \%$ & $24.1 \%$ & $20.3 \%$ & $14.1 \%$ & $23.9 \%$ \\
\hline Maintenance/repair & $15 \%$ & $15 \%$ & $17.4 \%$ & $9 \%$ & $17.1 \%$ & $12 \%$ & $7 \%$ & $25.1 \%$ \\
\hline Other expenses & $5 \%$ & $5 \%$ & $4.8 \%$ & $12 \%$ & $4.1 \%$ & $3.3 \%$ & $3.2 \%$ & $5 \%$ \\
\hline
\end{tabular}

Source: LEKA (2013).

Based on the analysis of the wood biofuel cost structure (see Table 1), it is estimated that about $80 \%$ of money paid by biofuel consumers for biofuel will re-enter the national economics in the form of taxes, salaries to Lithuanian nationals, forest owners, additional income of wood processing business, farmers' income, profit gained by the Lithuanian business (LEKA 2013). As a result, use of local biofuel would basically be more reasonable in economic terms compared to imported fuel, even if price of the latter was lower than of the local biofuel in commercial, but higher in macroeconomic sense.

\subsection{Experience acquired by establishing agro-forestry in Lithuania}

The major experience in the Lithuania so far has been acquired in terms of establishing willow clones/species (mainly Salix viminalis L., S. dasyclados Wimm., S. schwerinii E. Wolf., S. caprea L., S. burjatica Nasarow, Salix $\times$ mollissima Ehrh., S. alba L., S. fragilis L.) and Poplar (Populus spp.) plantations which are also considered as the most appropriate ones (Grigaliūnaite et al. 2013). Due to their high biomass yields, others varieties such as Alder (Alnus spp.), Giant reed (Arundo donax L.), Birch (Betula spp.), Hazel (Corylus avellana), Eucalyptus (Eucalyptus spp.), Ash (Fraxinus excelsior), Miscanthus (Miscanthus spp.), Black locust (Robinia pseudoaccacia) could be mentioned as promising crops for energy purpose. 
There are three basic groups of units which produce and process SRC biomass for energy purposes in Lithuania's production system. These are SRC planters (farmers and entrepreneurs), biomass purchasing companies (participants of the biofuel exchange and individual growers) and bio-energy production companies.

Lithuania was once under a thick forest cover which formed an over-ground organogenic layer, forest litter. Deforestation has resulted not only in the deterioration of the soil cover, but also affected the climate of the region. Lithuania's "single-zone" climate to entire regions means there is an incredibly high technical potential of energy plantations (Raslavičius et al. 2013). Usually, cultivation of SRC culture of willows and poplars as energy crops is suitable for land owners living longer distances away from their fields or wishing to pursue part-time farming. It is also a new possibility for traditional farmers to establish themselves in a dynamically expanding biofuel market without huge initial investments and maintenance costs. The major stages of SRC plantation establishment and management for energy purposes are as follows (Lygis et al. 2006):

- Selection of the area and soils for a plantation. Under conditions in Lithuania, the choice of the appropriate location is the most important factor driving the biomass yields of the energy crops. Alder (Alnus spp.), Birch (Betula spp.), Hazel (Corylus avellana), Eucalyptus (Eucalyptus spp.), Ash (Fraxinus excelsior), Black locust (Robinia pseudoaccacia) as well as different willow clones/species are a good choice. Poplar are particularly interesting for the following reasons: (i) their efficient use of resources and low input demand, (ii) the concentration of the yield in one harvest, (iii) their persistence and yield stability, (iv) their possible delayed harvest, (v) their high biomass yield potential. Selecting an area for a SRC plantation in Lithuania it is very important to assess the situation thoroughly according to logistic-economic, social and ecological aspects. The soil for SRC plantations have to be fertile and with low water-holding capacity allowed precipitation water to move beyond the root zone, whereas the more capacious clay loam retained the precipitation water within its root zone depth (Lygis et al. 2006; Letey, Vaughan 2013). Rather high potential of areas suitable for breeding of short rotation energy wood plantations is observed in Panevėžys (area - 2,178 km²), Šiauliai $\left(1,807 \mathrm{~km}^{2}\right)$, Kèdainiai $\left(1,677 \mathrm{~km}^{2}\right)$, Pakruojis (1,316 km²), Pasvalys $\left(1,289 \mathrm{~km}^{2}\right)$, Mažeikiai $\left(1,220 \mathrm{~km}^{2}\right)$, Joniškis $\left(1,152 \mathrm{~km}^{2}\right)$, Kupiškis $\left(1,080 \mathrm{~km}^{2}\right)$, Akmenè $\left(844 \mathrm{~km}^{2}\right)$, and Marijampole $\left(755 \mathrm{~km}^{2}\right)$ municipalities (Raslavičius et al. 2013). There are many different soil types in evidence in Lithuania (sand, sandy loam, clay, loam, etc.) that are suitable for extensive country-wide establishment of high-yield varieties of poplar (Populus spp.) and willow (varieties of the Common Osier; $S$. viminalis) plantations. It was found by Lygis et al. (2006), that the soils of higher fertility (productivity) guarantee a higher plantation increment, therefore, before establishing plantations in unfertile soils the economic effect must be calculated very thoroughly. Common osier plantations can be established in the fields that are flooded temporarily in spring (but not in wetlands) as aforementioned energy crops like consistent moisture all season. Peaty soils hardly retain sufficient amount of moisture during dry periods, therefore, it is not recommended to plant willows in peat bogs. Heavy, clay soils are particularly productive in Lithuania, especially when they contain high amounts of organic matter. In the initial growth stage, willows have a tendency of weak root development, but later the shrubs establish themselves and grow fast as such soils retain sufficient amounts 
of moisture. Under the climate conditions in Lithuania, it is best to plant willows in the first half of May, when soil has sufficient amount of moisture and the air temperature rises fast. Earlier planting is not recommended due to frequently occurring spring frosts. If soil has enough moisture, a willow plantation can be bred even in the beginning of June. The major factors regulating the area selection for SRC cultivation in Lithuania:

1) Biology of a tree species (clone, family, population);

2) It is distinctive to the national agro-forestry practice to define the configuration of SRC plantations in such a manner, that plantation rows do not exceed 200 meters in length (due to convenience for transporting raw biomass) and being adjusted to road network and other technological requirements (about $20 \%$ of the area usually is left unplanted, for biomass drying purpose). Furthermore, the plot configuration has to meet the basic principles of designing and managing forest landscapes to improve their value for biodiversity;

3) Legal limitations related with agricultural development and environmental protection. The Rules of Converting Non-forest Land to Forest (Official Gazette 2004) determinate the locations in which it is allowed to plant forest and where it is prohibited to do that. These rules include cases when arable land is converted into forest land. One of the most important criteria described in Official Gazette (2004) is soil fertility and productivity. Arable land is allowed to be converted into forest when the soil productivity index rating is lower than 32 and the purpose of land use is changed. Usually, soil productivity does not have to be a limiting factor, when forest plantations are established temporarily;

4) Under specific conditions in Lithuania, it is not expedient to breed energy crops in following locations: (i) in areas where plantations could decrease the value of natural landscape and have a negative visual impact, (ii) in recreation areas; (iii) in areas located farther than $50-100 \mathrm{~km}$ from the user or local biomass collection and distribution centre; (iv) in hilly areas, especially where slopes are steeper than 7-15\% (Lygis et al. 2006);

5) It is not expedient to convert a natural forest into plantation. It is not economically sound - stump elimination and deep continuous tillage $(40-60 \mathrm{~cm})$ are very expensive operations. In addition, forest proximity attracts wild hoofed animals and price of fencing can make up to a half of the plantation establishment cost;

6) SRC plantations can be planned in the major agricultural production regions and zones of ecological tension - as an alternative activity to intensive farming, contributing to the maintenance and ecological balance of the natural landscape (especially in the cases when small scale plantations are planned in the areas limited by the licensee for conventional afforestation);

7) Mechanized harvesting of energy crops pays dividends in large-scale plantations with the area exceeding 5-10 ha.

- Tillage. For many centuries Lithuanian farmers have gained rich experience with cultivating more or less fertile soils. From a local context, if a plantation is established on agricultural land, usually conventional tillage (disking, plowing and other methods) 
is used. However, those areas are often agricultural areas for food production with higher economic revenue. Mostly forests are grown on poorer soils, including abandoned agricultural land where agricultural production is less productive. Less fertile soils usually have been enriched before the artificially-established forest. Such farming system provides alternatives for increasing soil humus as well as application of lime and fertilizer. Both methods are able to positively influence soil compaction and yield crop under local conditions. According to our findings, in Lithuania, soil temperature and water dynamics have no significant differences in soil tillage patterns that could affect SRC yields. The resistance to abiotic and biotic impacts like drought, heat, insects and diseases for the most of the aforementioned above poplars and willow clones/species have been widely explored in Lithuania as well (Lygis et al. 2006).

- Planting material selection and preparation. According to local conditions and collected practice, planting is performed manually (in smaller areas) or by multi row drilling machines (in larger areas) in spring. We found that in the case when energy crops are growing in a large scale plantations, SRC planting density ranges from 1,000 to $20,000 \mathrm{pcs} /$ ha with rotation periods from 1 to 7 years. Usually, two main methods of cultivation are used: (i) very high density $(5,500-20,000 \mathrm{pcs} / \mathrm{ha}$; rotation period 1-4 years), and (ii) a high density (1,000-2,000 pcs/ha; rotation period 5-7 years).

- Weed management and fertilization. The management practice of SRC in Lithuania shows that short rotation coppice is generally considered to improve the water quality relative to conventional agricultural crops (Lygis et al. 2006) in a given area. It's due to the weed control only during the establishment phase, if chemical plant protection means are used (which reduces the organic matter input). Fertilization is performed with reference to the data of agrochemical analyses. The types and amounts of fertilizers depend on the soil, time of operating a plantation as well as on the amount of nutrients carried out with the harvest (Lygis et al. 2006). If the broad-spectrum herbicide is applied after ploughing to ensure rapid establishment of the SRC plantation, fertilisation is not normally necessary because there are enough nutrients available from the former usage (Dimitriou et al. 2011).

- Cutting and chip production. SRC harvesting consists of four main operations: cutting, collection, extraction and comminution (Verani et al. 2008). Salix viminalis L., S. dasyclados Wimm., S. schwerinii E. Wolf., and Populus spp. plantations in Lithuania are usually cut every 3-4 years in winter after leaves have fallen. Thus, the preparation process becomes faster, more flexible and less expensive. Under local climatic conditions, poplars and willows re-grow abundantly from the remaining stumps during the spring season. Ability to re-grow allows energy crops to be easily grown and propagated from unrooted cuttings. Cut-and-extract or cut-and-chip harvesters that pour the chips straight into tipper vehicles used to transport bulk products are usually used for harvesting works in the larger-scale SRC plantations. If plantation was cut by the cut-only or cut-and-bundle harvester, the machinery cuts the stems, laying them in windrows or collects them in bundles, which are dropped on the field. Chipping is the only operation delegated to a separate unit. 


\section{Energetic exploitation}

$\mathrm{CO}_{2}$ emissions from various solid biomass fuels combustion are traditionally assumed climate neutral if the bio-energy system is carbon flux neutral, i.e. the carbon dioxide released from biofuel combustion approximately equals the amount of carbon dioxide sequestered in biomass (Cherubini et al. 2011). In view of huge diversity of biofuel characteristics different technologies and methods can be applied for its combustion (Pereira et al. 2012; Ravelli et al. 2008; Yin et al. 2008). Woody biomass conversion technologies for heat and power production are mainly gasification, co-fired and direct-fired systems (see Table 2).

Table 2. Capacity range for wood biomass combustion technologies intended to heat and power production

\begin{tabular}{ll}
\hline Technology & Capacity, MW \\
\hline Direct-firing & \\
- Grate stoker boiler (stationary grate stoker, & $>1$; usually $8-50$ \\
moving (travelling) grate stoker) & max. 300 (in some cases) \\
- Fluidised bed combustion boilers: FBC, & $>5$; usually 15-25 \\
$\quad$ PFBC, CFB, BFB & max. 300 (in some cases) \\
\hline Co-firing & \\
- Pulverized coal boiler & usually $50-700$ \\
& max. 1000 (in some cases) \\
- Stoker boiler & usually $\leq 150$ \\
- Fluidised bed combustion boiler & usually $\leq 150$ \\
\hline Gasification (advanced conversion technology) & \\
- Fixed bed gasifier & usually 2-40 (thermal) and 2-15 (electric) \\
- Fluidized bed gasifier & usually 2-20 (thermal) and 1-5 (electric) \\
\hline
\end{tabular}

The use of woody biomass for fuel has a long tradition in EU-27 countries, including Lithuania. During the period from 1995 to 2013 biofuel consumption for energy production was constantly increasing in Lithuania. In the country, firewood and wood waste makes the main part of the cake of renewable energy resources. Therefore, SRC biomass has a huge potential to contribute to country's energy independence. By implementing the suitable combustion technologies (grate-firing, fluidised bed combustion, gasification, etc.) this target can be achieved in the decades to come.

\subsection{Evaluation of experience gathered in Lithuania}

Direct-firing (grate stoker). As shown in Figure 1 (AT 2014) usually modern grate-fired boilers consist of the following elements: (i) fuel supply system, (ii) grate assembly that supports the burning of biofuel and provides a pathway for the primary combustion air which is supplied through the grate under the SRC biomass charge, (iii) an over-fire air system that supplies additional air (secondary and tertiary) to complete combustion and reduce pollutant emissions to the atmosphere, (iv) boiler unit, (v) flue gas treatment system (bag filter, electrostatic filter, multi cyclone or combination of both), and (vi) ash removal system. 


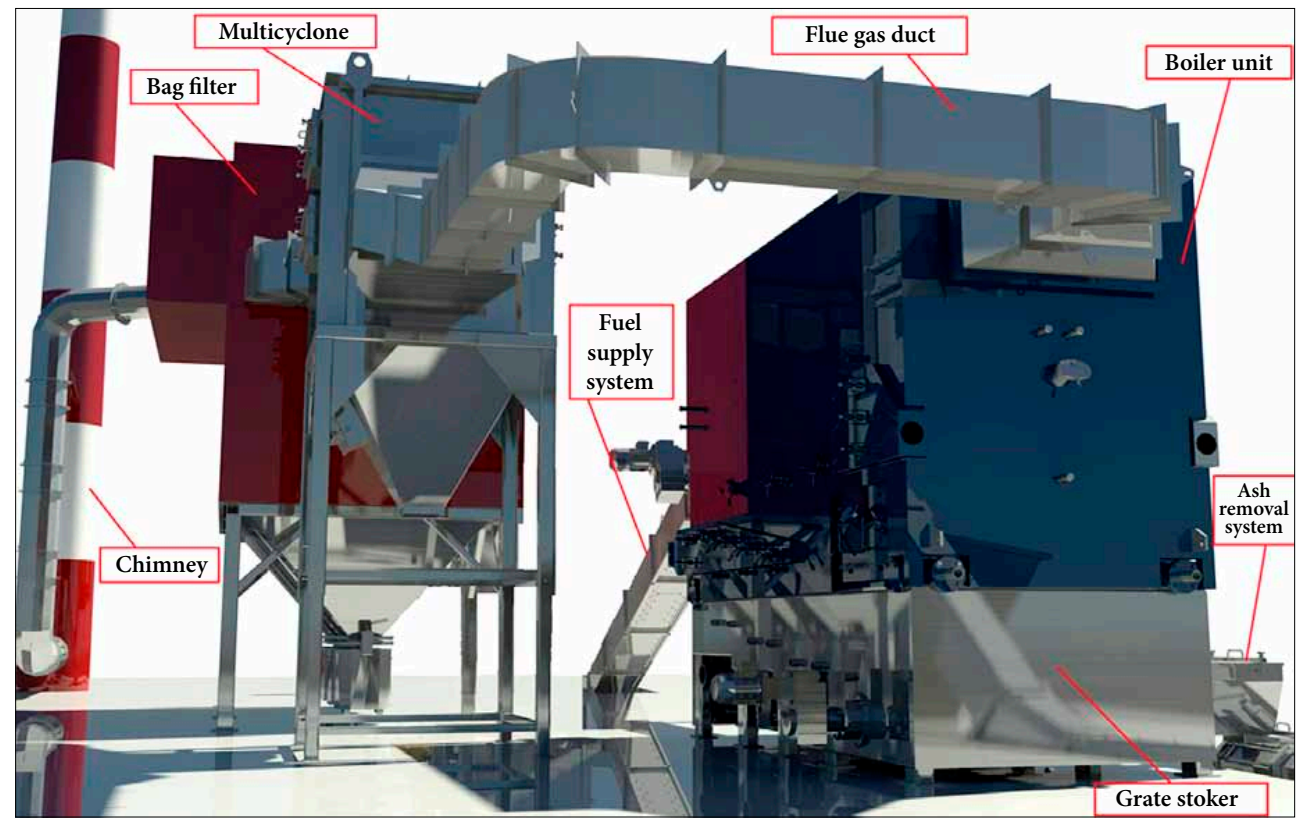

Fig. 1. The scheme of pilot boiler house installation intended for different kinds of solid biofuel

Nowadays, grates of different designs are usually used: light chain wheel fire grate; level, tilt, reciprocating fire grate; large flake chain fire grate; small flake chain fire grate; crossbeam chain fire grate, which can be divided into two groups - stationary and moving ones. Depending on boiler size, there could be one or several inspection doors and 2-3 or several sight glasses (see Fig. 2) for convenient operation and maintenance of the furnace. Modern, higher-efficiency furnace's masonry consists of two layers:

1) Shamote based bricks layer;

2) $100-150 \mathrm{~mm}$ thickness refractory board.

The air streams for combustion are divided into primary, secondary and tertiary. Primary air enters the combustion chamber through holes in the grate. The holes are designed in order to distribute air properly across the whole surface of the grate. Secondary and tertiary air is supplied above the layer of the fuel. A recirculation system of flue gases could be successfully introduced into primary, secondary, and/or tertiary zones. In primary zone (beneath the grate) recirculation helps to stabilize grate temperature. When fuel is dry, recirculation helps to decrease grate temperature, and when fuel moisture is high, recirculation helps to dry the fuel faster. Usually, recirculation is introduced into secondary (above the grate) and tertiary (in the additional combustion chamber) zones and helps to regulate temperature in the combustion chamber in order to maintain the constant temperature in various load ranges. The volatiles are usually combusted with secondary and tertiary air which has a wide range of regulation according to the type (moisture) of biomass-fuel being used. The combustion process is controlled fully automatically according to the heat demand: appropriate flows' adjustment allows to burn biofuel qualitatively, and with potentially less harmful emissions. 


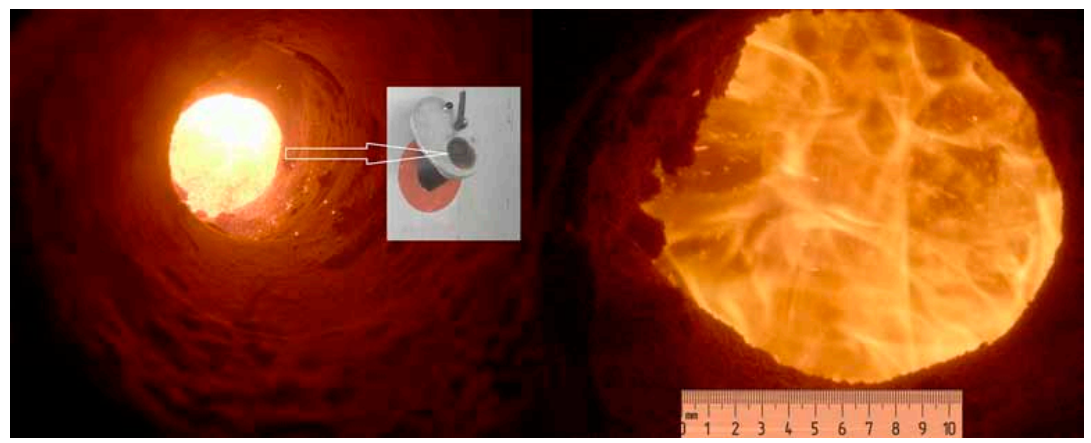

Fig. 2. Views from the visual observation window of the pilot biomass-firing stoker (fuel: wood pellets; flame temperature: $1091-1108^{\circ} \mathrm{C}$; surface (grate) temperature: $288-319^{\circ} \mathrm{C}$; temperature at $10 \mathrm{~cm}$ from the surface of the grate: $844-868^{\circ} \mathrm{C}$ )

In burning facilities, especially grate-fired boilers, the incomplete combustion process gives rise to higher emissions of $\mathrm{CO}$, hydrocarbons $\left(\mathrm{C}_{n} \mathrm{H}_{m}\right)$ and $\mathrm{NO}_{x}$ (Yin et al. 2008). Accordingly, the design of grate assembly and primary/secondary air supply systems split ratio plays a crucial role in the efficient and clean combustion of SRC biomass. Hence, because new biomass fuels (for example SRC biomass) are not well-defined yet regarding their combustion behaviour, fuel characterization with a special focus on combustion-related fuel properties is a first important step for their wider introduction (Sommersacher et al. 2012). Internal localized corrosion, formation of slag and derivative products are reported to be the predominant failure mechanism of boilers, grate assemblies, flue gas ducts, etc. Elemental composition of SRC biomass and its chemical exposure is shown in Table 3.

Table 3. Elemental composition of SRC biomass and its chemical exposure

\begin{tabular}{ll}
\hline Chemical element & Effect on \\
\hline $\mathrm{C}$ (Carbon) & Upper heating value \\
\hline $\mathrm{Ca}$ (Calcium) & Increase in ash melting temperatures \\
\hline $\mathrm{Cl}$ (Chlorine) & $\begin{array}{l}\text { HCl formation; Presence of the chlorine compounds (mixtures of different } \\
\text { dioxins and furanes) in the exhaust gases; High temperature corrosion }\end{array}$ \\
\hline $\mathrm{F}$ (Fluorine) & Presence of Hydrogen fluoride in the exhaust gases; Corrosion \\
\hline $\mathrm{H}$ (Hydrogen) & Upper heating value; Lower heating value \\
\hline $\begin{array}{l}\text { Heavy metals } \\
\text { (Pb, Ni, Cd, } \mathrm{Zn}, \mathrm{Cr})\end{array}$ & $\begin{array}{l}\text { Hazardous compounds in the flue gas; Ash melting; Aerosol formation; } \\
\text { Corrosion }\end{array}$ \\
\hline $\mathrm{K}$ (Potassium) & $\begin{array}{l}\text { Corrosion in heat exchangers; Low ash melting temperatures; Boiler furnace } \\
\text { slagging; Aerosol formation; High temperature corrosion }\end{array}$ \\
\hline $\mathrm{Mg}$ (Magnesium) & Increase in ash melting temperatures \\
\hline $\mathrm{N}$ (Nitrogen) & Presence of $\mathrm{NO}_{x^{\prime}} \mathrm{N}_{2} \mathrm{O}$ in the exhaust gases \\
\hline $\mathrm{Na}$ (Natrium) & $\begin{array}{l}\text { Corrosion in heat exchangers; Low ash melting temperatures; Boiler furnace } \\
\text { slagging; Aerosol formation; High temperature corrosion }\end{array}$ \\
\hline $\mathrm{O}$ (Oxygen) & Upper heating value \\
\hline $\mathrm{P}$ (Phosphorus) & Ash melting; Aerosol formation \\
\hline $\mathrm{S}$ (Sulphur) & Presence of $\mathrm{SO}_{2}$ in the exhaust gases; Low temperature corrosion \\
\hline
\end{tabular}




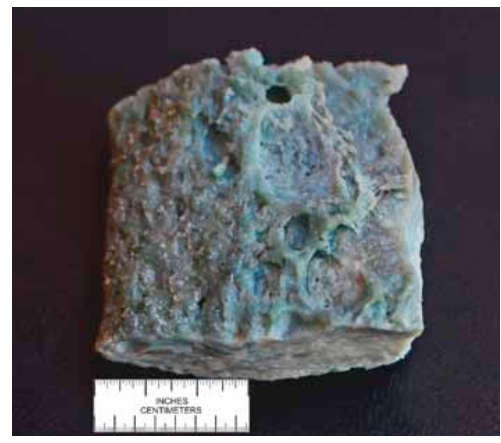

Fig. 3. Deposit formation pattern from the pilot biomass-firing stoker found during the annual maintenance procedure (Photo by A. Baleckis)
The firing of almost any type of solid biofuel like wood materials and energy crops in combustion utilities may suffer from severe deposition as well. A typical deposit formation pattern from the pilot biomass-firing stoker is shown in Figure 3.

The local practice survey confirms the research data presented by Yin et al. (2008), that deposits reduce both the overall process efficiency and the heat transfer in the boiler, while corrosion reduces the lifetime of the installation.

The design and selection of any biomass combustion system is mainly determined by the characteristics of the fuel to be used, local environmental legislation, the costs and performance of the equipment necessary or available as well as the energy and capacity needed (heat, electricity) (Van Loo, Koppejan 2008). Accordingly, the designer of the combustion equipment and boiler plant must have the appropriate fuel assessment and design tools. The most suitable technology package therefore can vary from case to case but generally, due to economy of scale effects concerning the complexity of the fuel-feeding system, the combustion technology and the flue gas cleaning system, large-scale systems use lowquality fuels and high quality fuels are necessary for small-scale systems (Van Loo, Koppejan 2008). Other key components of biomass fired plant are stack, condensing economizer unit (optional) (see Fig. 4), as well as associated sampling and monitoring system.

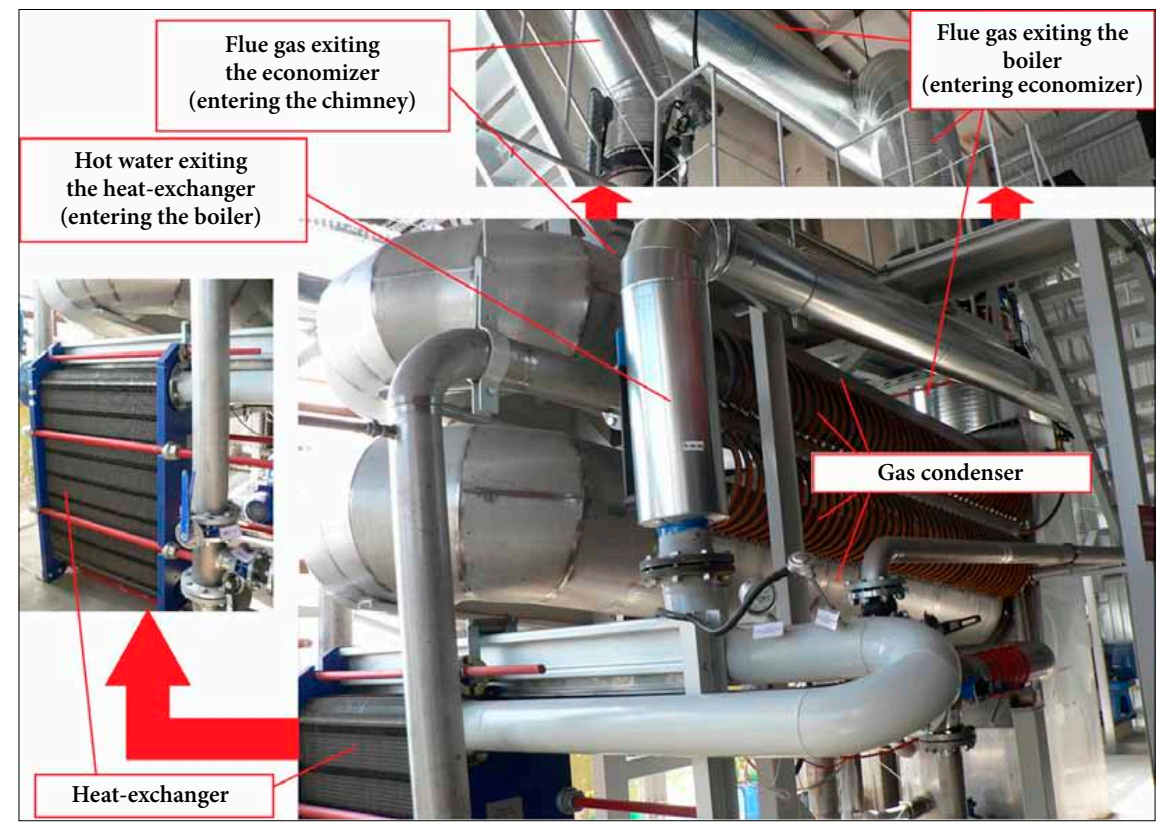

Fig. 4. Condensing economizer unit at biofuel CHP 
The main aim of the electricity producers is optimising the use of the recovered energy (Saidur et al. 2010; Wang et al. 2012). By installing a condensing economiser as shown in Figure 4, CHP plant (or boiler house) can improve overall heat recovery (both latent and sensible heat from the flue gas) and steam system efficiency by up to $10 \%$. Condensing economisers require site-specific engineering and design, and a thorough understanding of the effect they will have on the existing steam system and water chemistry. The condensing economiser removes heat from hot flue gases by passing them through one or more shell-and-tube or tubular heat exchangers.

Direct-firing (Fluidised bed combustion boilers) is a combustion technology used in power plants. FBC boilers are the most recent type of the boilers developed for solid fuel combustion. The primary driving force for development of FBC is reduced sulfur dioxide and mono-nitrogen oxides emissions from coal combustion. Fluidised bed combustion systems fit into three major groups: (i) first-generation pressurised PFBC systems, (ii) atmospheric FBC systems, (iii) second-generation PFBC systems; and two subgroups entitled as circulating fluidized bed (CFB) and bubbling fluidised bed (BFB), respectively (Koorneef et al. 2007; Ravelli et al. 2008; Valmari et al. 1998). The use of FBC is related to biomass and other low-calorific value fuels that permit operating boilers without tubes in the dense bed to avoid erosion, also in the case of BFB (Leckner 2011). The example of best practice is Eon Stevens Croft Wood Burning Plant, Lockerbie, Scotland. This 44MWe plant was commissioned in August 2007 and is the UK's largest dedicated wood burning plant. Its capacity is $475,000 \mathrm{t}$ of wood (SRC willow) per year, which feed a bubbling fluidised bed boiler (Leckner 2011).

In a case of a stationary fluidised bed boiler, combustion takes place in the bed made of inert materials and slag. Air flow required for combustion rises, keeping the bed in a floating state. In SFB boilers, combustion takes place in the dense bottom bed, except for tiny fuel particles that burn in particle suspension above the bed. As a result of intensive mixing of solid particles, combustion is rapid and uniform (non-laminar), with combustion temperature kept below NOx formation temperature. Various fuel and fuel mixtures can be fired in fluidized bed systems. Specific combustion technology allows firing high-ash-content fuel, including agri-waste. Low combustion temperature prevents from NOx formation, thus keeping the temperature below ash melting point.

One way energy crops can be used to generate electricity is in a steam boiler, which is the same process used to convert coal to electricity (Launder 2002). The steam can be used directly for heating purposes as well (DOE/EE-0288 2004).

\subsection{Evaluation of experience gathered in EU-27 countries}

Co-firing (Fluidised bed combustion boilers). One of the most attractive decisions about using SRC biomass is co-firing with coal in existing utility boilers that generate heat energy by burning coal. It is an easily implemented and moderate investment requiring biomass-to-energy technology. In the near term, it is the most feasible development option for introducing new large- and medium-scale dedicated biomass power generation in Lithuania. During biomass co-firing, the matter of biological origin can substitute for up to $20 \%$ of the coal used in the 
boiler. The SRC biomass and the fossilised carbon are combusted simultaneously. When it is used as a supplemental fuel in an existing coal-fired boiler, plant-derived materials can provide the following benefits (DOE/EE-0288 2004): they are more austere and less investment is needed (most of the existing equipment can be used without major modifications); reductions in Sulfur dioxide, mono-nitrogen oxides $\mathrm{NO}$ and $\mathrm{NO}_{2}$, Carbon dioxide, and other atmospheric emissions; avoidance of landfill costs; lower fuel costs. Typically technological lines and complexes include biofuel storage and handling systems, but some facilities may also need to add feedstock drying and size-reduction (Raslavičius et al. 2011; Van Loo, Koppejan 2008).

Direct co-firing of fuel mixtures is the cheapest, simplest and most common approach of bioenergy production. In direct co-firing, biomass and fossil fuel are co-milled in certain proportion and fed into the furnace. This biomass mixture firing technology can be applied for various types of fluidised bed and stoker furnaces. Low power output (below $50 \mathrm{MW}$ ) boilers are equipped with fluidised bed furnaces with stationary or moving grates. Boilers of the high capacity come with bubbling fluidised bed (50-100 MW) or circulating fluidised bed (CFB) (100-300 MW) furnaces.

Indirect co-firing. In indirect co-firing technology, solid biomass is first converted into gaseous or liquid fuel by a gasification/pyrolysis reactor, and subsequently fired with coal in a coal-fired furnace. The key advantage of indirect co-firing is separated flows of biomass and coal. Besides, there is a wider choice of types of biomass that can be used due to gasification. Gas can be additionally treated if it is required to reduce negative effect on performance of the boiler. Indirect co-firing of fuel mixtures is definitely more expensive than direct co-firing, as the former requires biomass gasification/pyrolysis reactor.

Parallel co-firing (hybrid systems). In parallel co-firing, also referred to as co-firing in hybrid systems, biomass and fossil fuel are fired in separate boilers, with the resulting gas fed into a common header. Considerably higher capital investment is required to build parallel co-firing facilities than in direct co-firing. Rationale behind building new parallel co-firing power plants is the possibility to use rather complex fuel with high chlorine and alkaline content and separation of ash from different types of fuel. This technology reduces the risk of slagging and fouling of heat exchange surfaces caused by specific chemical properties of SRC biomass ash, such as high content of alkaline metals and low melting point.

Central and Eastern European electricity sectors are in general deficit of knowledge on the newest technologies on co-firing of wood biomass (including SRC biomass) with fossil fuels, impact of co-firing on the plant itself and ways to optimize the fuel supply chain to avoid distortions in local biomass markets, such as competition with other electricity and/or heat producers or other sectors using biomass (FP6-2005-TREN-4 2009). Yet, many plants are taking the risk of testing co-firing technologies. There are about 1000 coal-fired power plants in Europe. The biomass share (in energy terms) is 15\% in fluidised bed boilers and 10\% in other boilers. As of EU-27 countries, Cyprus, Latvia, Lithuania, Luxembourg, and Malta lack coal-fired power (Hansson et al. 2009). Therefore, there is a need to increase knowledge on crucial co-firing issues among market actors to allow them a sound decision on starting co-firing of biomass and enhance optimal use of this technology (FP6-2005-TREN-4 2009). Lithuania has a big potential to successfully introduce this technology for country-wide energy generation. 
Gasification is a process that converts organic based carbonaceous materials into hydrogen and carbon monoxide rich gas, called syngas (synthesis gas) (Jansen 2011). This is achieved by heating solid biomass in an oxygen-starved environment at high temperatures, without combustion, with a controlled amount of oxygen (or steam). The gasifier is a specially designed reactor that heats biomass in a low-oxygen environment to produce a fuel gas. Gasifiers are mainly characterised according to the direction of flow of feedstock, and air or oxygen is introduced into them. The process itself is divided into two stages: (i) devolatilisation (temperature range $200-600{ }^{\circ} \mathrm{C}$ ), and (ii) gasification of the remaining char (temperature range $700-850^{\circ} \mathrm{C}$ ) (Jansen 2011). Calorific value of the produced syngas ranges from 2 to $12 \mathrm{MJ} / \mathrm{nm}^{3}$ (natural gas - 34-44 MJ/nm $\mathrm{nm}^{3}$ ). Fixed bed updraft, fixed bed downdraft, circulating fluidised bed, bubbling fluidised bed, entrained flow and multi-stage gasifiers are being commonly used for different applications. Through gasification, dedicated energy crops could be used for electricity generation via turbines, heating and the production of chemicals (Biomass CHP Catalog 2007). It is predicted that gasification systems could have efficiencies double that of current combustion systems (Launder 2002). A major challenge for gasification development, especially for new power generation, is the extremely high capital investment required to build new facilities (Launder 2002). Unlike efficient and clean biomass conversion in the high-efficiency coal boilers, current facilities cannot be inexpensively converted to a gasification process (Biomass CHP Catalog 2007; Pereira et al. 2012; Ruiz et al. 2013).

Direct or indirect co-firing technologies can be used in gasification. In direct co-firing, biomass is co-fired with fuel in the same chamber. Small amount of air to sustain combustion also acts as an oxidizer of nitrogen, which usually results in low energy value $\left(2.5-8.0 \mathrm{MJ} / \mathrm{m}^{3}\right)$ of the generated gas. Such gas can be used in heating boilers. In indirect co-firing, fuel is fired separately from biomass that is injected with very small amount of oxygen or steam. Steam improves gas composition by increasing hydrogen content and energy value to $20 \mathrm{MJ} / \mathrm{m}^{3}$. Such gas can be used both in boilers, and in gas turbines. Gasification occurs in chambers with atmospheric pressure or pressurized to 20 bar.

Gas generation facilities are integrated with combustion facilities, as the generated gas mixture cannot be accumulated. Producer gas (PG) is the mixture of gases produced by the gasification of biomass (organic material) at relatively low temperatures $\left(700^{\circ} \mathrm{C}\right.$ to $1000^{\circ} \mathrm{C}$ ). It is composed of carbon monoxide, hydrogen, $\mathrm{CO} 2$ and typically a range of hydrocarbons such as methane (CH4) with nitrogen from the air (Sadaka 2003). PG can be burned as a fuel gas such as in a boiler for heat or in an internal combustion gas engine for electricity generation or combined heat and power. For direct combustion in boilers it is not required to clean the producer gas. Usually, the composition of the PG can be modified by manipulation of gasification parameters (Sadaka 2003). Gas turbines are usually used for gas combustion, as they are more efficient and simple compared to steam turbines. Gas is usually pre-treated prior to combustion by removing soot, tar and other adverse components. In case the gas intended for combustion has been pre-mixed with natural gas, treatment technology is usually fairly simple. However, gas intended for fuel synthesis (for production of fuel cells or synthetic liquid fuels) must be cleaned of all impurities.

SWOT analysis (Strengths, Weaknesses, Opportunities, Threats) has been carried out to identify the key strengths, major weaknesses, opportunities, and threats of the gasification technology (see Table 4). 
Table 4. Gasification: SWOT analysis

\begin{tabular}{|c|c|}
\hline STRENGTHS & WEAKNESSES \\
\hline $\begin{array}{l}\text { - Use of biofuel } \\
\text { - Decentralized power generation in small areas } \\
\text { - Ecologically clean technology } \\
\text { - Additional fuel for industry } \\
\text { - Biofuel is cheaper than fossil fuel and more } \\
\text { sustainable } \\
\text { - Saving of conventional fossil fuel resources } \\
\text { - The fuel is easy to obtain (e.g. by growing } \\
\text { energy crops) }\end{array}$ & $\begin{array}{l}\text { - Syngas must undergo a series of treatment } \\
\text { processes to remove tar and particles } \\
\text { - Strict quality control of the fuel is required } \\
\text { - The fuel is bulky, difficult to prepare } \\
\text { - Long start-up period ( } 30 \text { min) } \\
\text { - Gasifier start-up or shutdown processes } \\
\text { produce a considerable amount of soot that } \\
\text { must be removed from the system } \\
\text { - High operating costs }\end{array}$ \\
\hline OPPORTUNITIES & THREATS \\
\hline $\begin{array}{l}\text { - Can be powered by different types of engines } \\
\text { - Can use various types materials: chips (energy } \\
\text { crops, wood pellets), sawdust, charcoal etc. } \\
\text { - The technology requires comprehensive } \\
\text { analysis and further improvement }\end{array}$ & $\begin{array}{l}\text { - Syngas may form an explosive mixture with } \\
\text { air when mixed in certain proportions } \\
\text { - Little experience }\end{array}$ \\
\hline
\end{tabular}

\subsection{Evaluation of woody biomass conversion technologies}

What is missing from the previous studies, however, is which biomass conversion technologies have the impact on Lithuanian energy sector, and what limits the ability of commercialization success for other, more advanced, technologies. What are the characteristics that are the root of this impact? Are there fundamental differences between these technologies and others advanced ones - that will transform local bio-energy sector in the future?

The intent of developing a juxtaposition of the characteristics (see Table 5), presented in sub-sections 3.1 and 3.2, is that it could lead to a better understanding of the stages of technical development of the woody biomass conversion technologies. In this way, it might be possible to examine the new biomass-to-energy projects before the initial ideas stage (not, as is the usual case, in the pre-Tender stage, which includes two sub-stages: appointment of consultant, and preparation of detailed project report) to determine their potential advantages and weaknesses. A more accurate assessment and comparison of biomass conversion technologies can be made using a variety of multicriteria methodologies (Scott et al. 2012; Hashemkhani Zolfani, Saparauskas 2013; Yazdani-Chamzini et al. 2013; Zavadskas et al. 2014a; Bagočius et al. 2014; Kildienè et al. 2014; Tamošaitienè, Gaudutis 2013).

The technical characteristics given above are not necessarily unique to all types and possible modifications of the aforementioned biomass conversion technologies. However, in many instances, (like in the case of gasification), the lack of specific knowledge have created situations that were previously impossible to be solved (to reach their technical accomplishment and execution of a commercial-level) without the aid of numerous $\mathrm{R} \& \mathrm{D}$ activities in which developers do not capture all of the economic benefits that the technology provides. Furthermore, even though other technologies like biomass gasification may have sustainability impacts similar to direct-firing, currently grate-firing of biomass in Lithuania has greatly amplified its effects to the point of entirely overshadowing any other technology's impact. 
Table 5. Juxtaposition of woody biomass conversion technologies

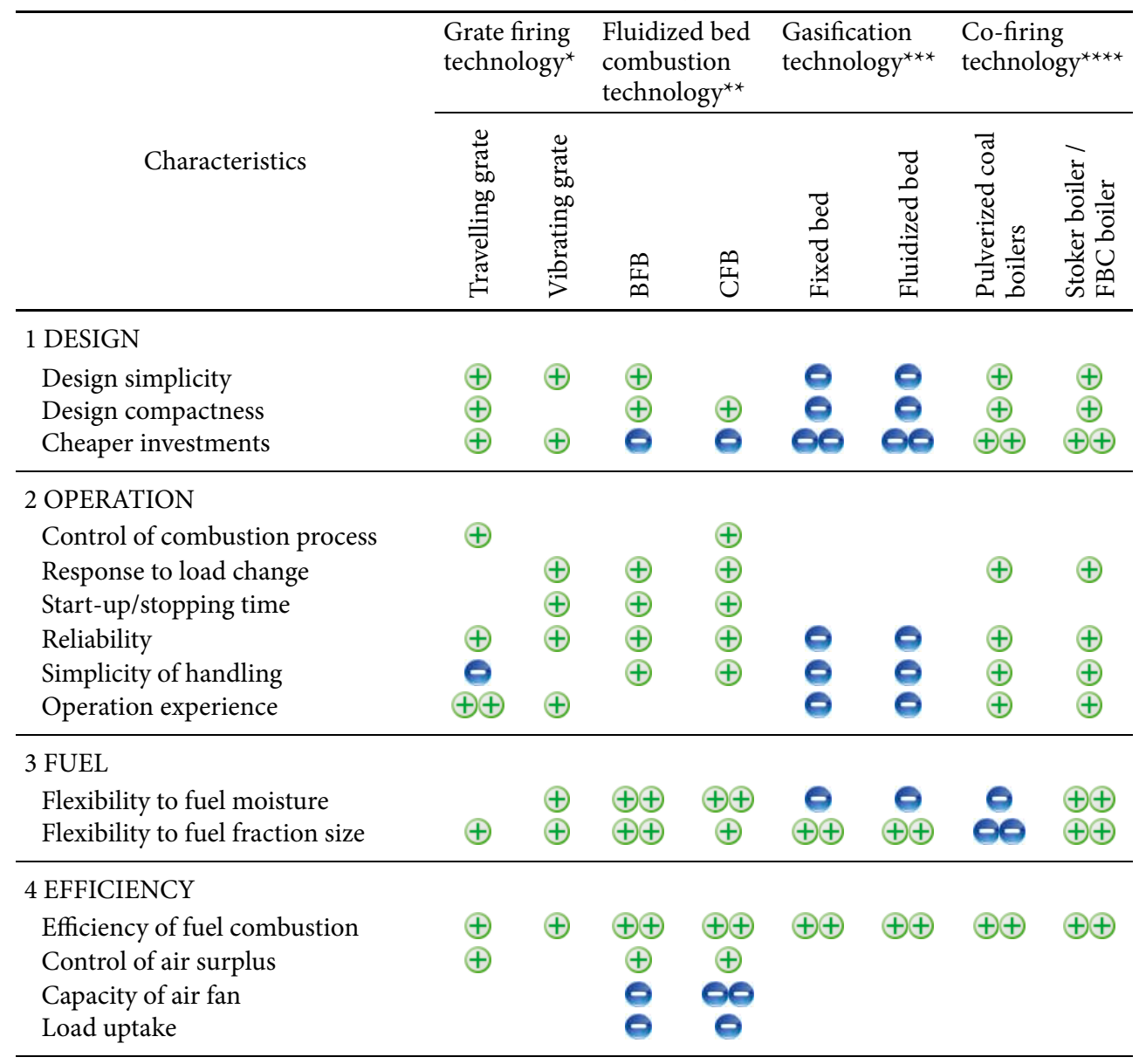

\section{ENVIRONMENTAL}

Prevention of $\mathrm{NO}_{\mathrm{X}}$ formation

Option of reducing sulphur oxides

Solid particles emission

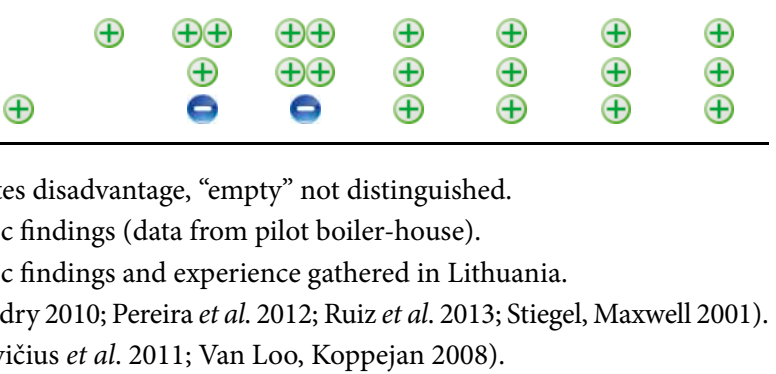

Note: “†” indicates advantage, “” indicates disadvantage, "empty” not distinguished.

* - Co-authors presenting new scientific findings (data from pilot boiler-house).

** - Co-authors presenting new scientific findings and experience gathered in Lithuania.

*** - (Biomass CHP Catalog 2007; McKendry 2010; Pereira et al. 2012; Ruiz et al. 2013; Stiegel, Maxwell 2001).

**** - (Biomass CHP Catalog 2007; Raslavičius et al. 2011; Van Loo, Koppejan 2008).

\section{Conclusions}

The concept of cultivation and energetic exploitation of biomass from SRC has and will continue to be an important component of the development of a supply chain to energy security and a low carbon transition in many developing countries in general and in Lithuania 


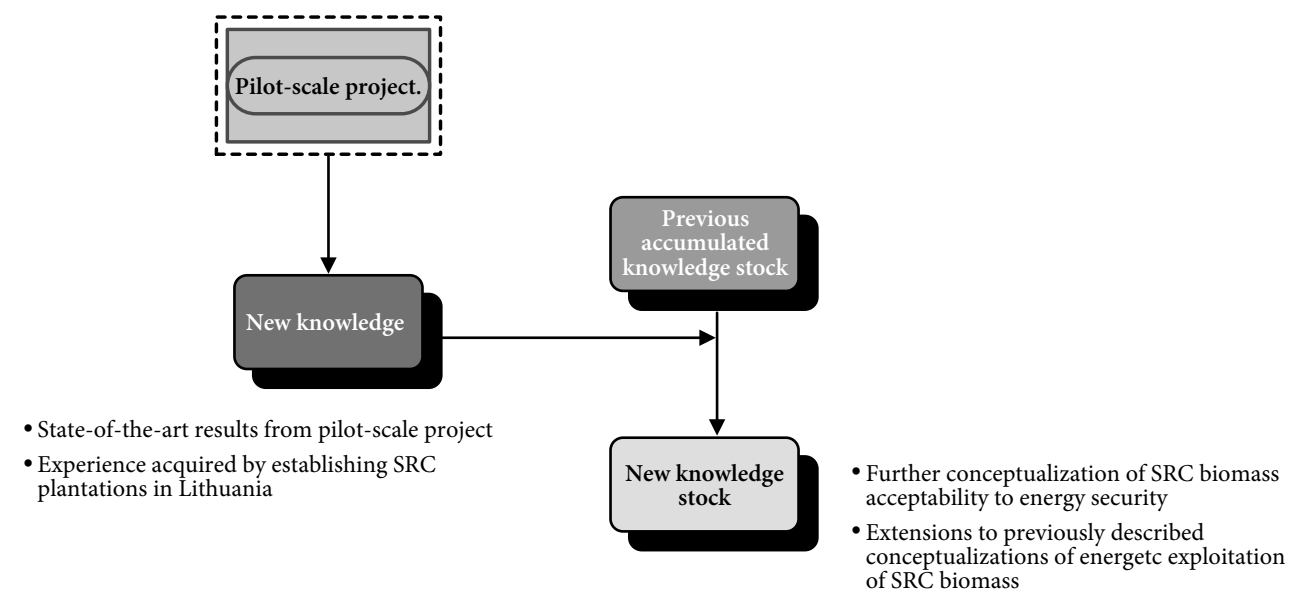

Fig. 5. The key research achievements of the pilot-scale project

in particular. The extension of previous conceptualisations of SRC biomass acceptability is provided in light of progress and recent trends within the mentioned above areas. The key research achievements of the pilot-scale project are presented in Figure 5.

SRC biomass is being applied in new and innovative ways to heat buildings and generate electricity. This has led to a growing biomass energy industry worldwide. Future growth of the industry will be shaped by different challenges and opportunities such as cost competitiveness of technologies, transmission issues, huge untapped potential, environmental concerns, government policies, and competing demands for biomass feedstock. Biomass energy has some environmental impacts. The emissions depend on the choice of biomass materials and the technologies and pollution controls used. The development of large-scale energy crops, such as willow and poplar SRC, for the production of biofuels could lead to decreases in pesticide and fertiliser use that are harmful to wildlife and habitat as well. The number of boiler-houses using wood waste as fuel is increasing fast in Lithuania as wood fuel is relatively cheap and hardly pollutes the environment. The growth of demand in the wood waste market may result in an increase of demand for this type of fuel in the nearest future. On this understanding, plantations for energy purposes have future in order to satisfy energy needs and further developments in sustainability.

\section{References}

AT. 2014. JSC Axis Technologies data [online], [cited 15 January 2014]. Available from Internet: http://www.axis.lt

Bagočius, V.; Zavadskas, E. K.; Turskis, Z. 2014. Multi-person selection of the best wind turbine based on the multi-criteria integrated additive-multiplicative utility function, Journal of Civil Engineering and Management 20(4): 590-599. http://dx.doi.org/10.3846/13923730.2014.932836

Baltodano, J. 2000. Monoculture forestry: a critique from an ecological perspective, in Tree trouble: $a$ compilation of testimonies on the negative impact of large-scale monoculture tree plantations prepared for the 6 th COP of the FCCC. Friends of the Earth International.

Berndes, G.; Börjesson, P.; Ostwald, M.; Palm, M. 2008. Multifunctional biomass production systems an overview of specific applications in India and Sweden, Biofuels, Bioproducts and Biorefining 2(1): 16-25. http://dx.doi.org/10.1002/bbb.52 
Biomass CHP Catalog. 2007. Biomass combined heat and power catalog of technologies. U. S. Environmental Protection Agency, Combined Heat and Power Partnership, September 2007.

Cherubini, F.; Peters, G. P.; Berntsen, T.; Stromman, A. H.; Hertwich, E. 2011. CO2 emissions from biomass combustion for bioenergy: atmospheric decay and contribution to global warming, Global Change Biology. Bioenergy 3(5): 413-426. http://dx.doi.org/10.1111/j.1757-1707.2011.01102.x

Cherubini, F.; Strømman, A. H. 2011. Life cycle assessment of bioenergy systems: state of the art and future challenges, Bioresource Technology 102(2): 437-451. http://dx.doi.org/10.1016/j.biortech.2010.08.010

Dimitriou, I.; Baum, C.; Baum, S.; Busch, G.; Schulz, U.; Köhn, J.; Lamersdorf, N.; Leinweber, P.; Aronsson, P.; Weih, M.; Berndes, G.; Bolte, A. 2011. Quantifying environmental effects of short rotation coppice (SRC) on biodiversity, soil and water. IEA Bioenergy. Task 43: 2011:01.

Directive 2009/28/EC. 2012. On the promotion and use of energy from renewable sources. New Commission proposal to minimise the climate impacts of biofuel production: Press release. Brussels, 17 October 2012.

Djomo, S. N.; El Kasmioui, O.; Ceulemans, R. 2011. Energy and greenhouse gas balance of bioenergy production from poplar and willow: a review, Global Change Biology. Bioenergy 3: 181-197. http://dx.doi.org/10.1111/j.1757-1707.2010.01073.x

DOE/EE-0288. 2004. Biomass cofiring in coal-fired boilers. U.S. Federal Energy Management Program. Department of Energy Energy Efficiency and Renewable Energy.

Drewer, J.; Finch, J. W.; Lloyd, C. R.; Baggs, E. M.; Skiba, U. 2012. How do soil emissions of $\mathrm{N}_{2} \mathrm{O}, \mathrm{CH}_{4}$ and $\mathrm{CO}_{2}$ from perennial bioenergy crops differ from arable annual crops?, Global Change Biology. Bioenergy 4: 408-419. http://dx.doi.org/10.1111/j.1757-1707.2011.01136.x

FP6-2005-TREN-4. 2009. Co-firing - from research to practice: technology and biomass supply know-how promotion in Central and Eastern Europe. Project reference: 38479. Funded under: FP6-SUSTDEV.

Goglio, P.; Owende, P. M. O. 2009. A screening LCA of short rotation coppice willow (Salix sp.) feedstock production system for small-scale electricity generation, Biosystems Engineering 103: 389-394. http://dx.doi.org/10.1016/j.biosystemseng.2009.03.003

Grigaliūnaitè, B.; Stackevičienè, E.; Matelis, A. 2013. Fungi on introduced Salix “Gudrun”, Optimization of Ornamental and Garden Plant Assortment, Technologies and Environment: Scientific Articles 4(9): 46-49.

Grzybek, A. (Ed.). 2010. Modelling of biomass utilisation for energy purpose. Bioforsk FOKUS 5(6). Institute of Technology and Life Sciences. $138 \mathrm{p}$.

Hansson, J.; Berndes, G.; Johnsson, F.; Kjärstad, J. 2009. Co-firing biomass with coal for electricity generation - an assessment of the potential in EU27, Energy Policy 37(4): 1444-1455. http://dx.doi.org/10.1016/j.enpol.2008.12.007

Harris, P. J. C.; Wright, J. E.; Trenchard, E. J. 2011. Potential for rainfed woody biomass production for energy conversion in drought and salinity areas of Northern India, Journal of Scientific \& Industrial Research 70(8): 577-582.

Hashemkhani Zolfani, S.; Saparauskas, J. 2013. New application of SWARA method in prioritizing sustainability assessment indicators of energy system, Inzinerine ekonomika - Engineering Economics 24(5): 408-414.

Jansen, T. 2011. Gasification of woody biomass. Internship at SINTEF Energi AS. University of Twente.

Kamath, V. 2012. India's energy crisis [online], [cited 12 September 2013]. Available from Internet: http://www.wallstformainst.com/2012/07/17/indias-energy-crisis

Kildienè S.; Zavadskas, E. K.; Tamošaitienè, J. 2014. Complex assessment model for advanced technology deployment, Journal of Civil Engineering and Management 20(2): 280-290. http://dx.doi.org/10.3846/13923730.2014.904813

Kim, S. K.; Lee, B. G.; Park, B. S.; Oh, K. S. 2011. The effect of r\&d technology commercialization capabilities and innovation performance, Technological and Economic Development of Economy 17(4): 563-578. http://dx.doi.org/10.3846/20294913.2011.603481 
Koorneef, J. M.; Junginger, H. M.; Faaij, A. P. C. 2007. Development of fluidized bed combustion - an overview of trends, performance and cost, Progress in Energy and Combustion Science 33(1): 19-55. http://dx.doi.org/10.1016/j.pecs.2006.07.001

Launder, K. 2002. Energy crops and their potential development in Michigan. A Report of the Michigan Biomass Energy Program (MBEP) [online], [cited 11 February 2013]. Available from Internet: http://www.michigan.gov.

Leckner, B. 2011. Developments in Fluidized Bed Conversion during 2005-2010: a summary from the member countries of the IEA-FBC Implementing Agreement. Chalmers University of Technology, Göteborg, Sweden.

LEKA. 2013. Biokuro potencialo Lietuvoje įvertinimas, biokuro kainu prognozé, biokuro panaudojimo socialinès naudos juvertinimas ir biokuro panaudojimo plètrai reikalingu Valstybès intervencijų pasiūlymai. Baigiamoji ataskaita. Lietuvos energetikos konsultantu asociacija, Lithuania. 45 p. (in Lithuanian).

Letey, J.; Vaughan, P. 2013. Soil type, crop and irrigation technique affect nitrogen leaching to groundwater, California Agriculture 67(4): 231-241. http://dx.doi.org/10.3733/ca.E.v067n04p231

Lygis, V.; Matelis, A.; Stackeviciene, E.; Simenas, J. 2006. Preparation of the guidelines for plantation afforestation, production and use. Report No. SBMŪRP5-108. Institute of Botany of Nature Research Centre, Lithuania. (in Lithuanian).

McKendry, P. 2010. Energy production from biomass (part 3): gasification technologies, Bioresource Technoly 83(1): 56-63. http://dx.doi.org/10.1016/S0960-8524(01)00120-1

Official Gazette. 2004. Miško įveisimo ne miško žemejje taisyklès [Rules of converting non-forest land to forest]. Žin. 2004, Nr. 55-1918, Nr. 142-5215; 2006, Nr. 120-4570; 2009, Nr. 30-1204; 2010, Nr. 124-6340. (in Lithuanian).

Otter, C. L. 2007. Guidelines for developing and evaluating a request for proposal [online]. State of Idaho, Division of Purchasing. January 2007 [cited 15 January 2014]. Available from Internet: http://purchasing.idaho.gov.

Pereira, E. G.; da Silva, J. N.; de Oliveira, J. L.; Machado, C. S. 2012. Sustainable energy: a review of gasification technologies, Renewable and Sustainable Energy Reviews 16(7): 4753-4762.

http://dx.doi.org/10.1016/j.rser.2012.04.023

Raslavičius, L. 2012. Renewable energy sector in Belarus: a review, Renewable and Sustainable Energy Reviews 16(7): 5399-5413. http://dx.doi.org/10.1016/j.rser.2012.04.056

Raslavičius, L.; Grzybek, A.; Dubrovin, V. 2011. Bioenergy in Ukraine - possibilities of rural development and opportunities for local communities, Energy Policy 39: 3370-3379.

http://dx.doi.org/10.1016/j.enpol.2011.03.032

Raslavičius, L.; Kučinskas, V.; Jasinskas, A. 2013. The prospects of energy forestry and agro-residues in the Lithuania's domestic energy supply, Renewable and Sustainable Energy Reviews 22: 419-431. http://dx.doi.org/10.1016/j.rser.2013.01.045

Ravelli, S.; Perdichizzi, A.; Barigozzi, G. 2008. Description, applications and numerical modelling of bubbling fluidized bed combustion in waste-to-energy plants, Progress in Energy and Combustion Science 34(2): 224-253. http://dx.doi.org/10.1016/j.pecs.2007.07.002

Ravindranatha, N. H.; Hall, D. O. 1996. Estimates of feasible productivities of short rotation tropical forestry plantations, Energy for Sustainable Development 2(5): 14-20. http://dx.doi.org/10.1016/S0973-0826(08)60157-X

Ruiz, J. A.; Juarez, M. C.; Morales, M. P.; Munoz, P.; Mendivil, M. A. 2013. Biomass gasification for electricity generation: review of current technology barriers, Renewable and Sustainable Energy Reviews 18: 174-183. http://dx.doi.org/10.1016/j.rser.2012.10.021

Sadaka, S. 2003. Gasification, producer gas and syngas. Agriculture and Natural Resources, Arkansas: University of Arkansas Cooperative Extension Service Printing Services. FSA1051- PD-5-09N.

Saidur, R.; Ahamed, J. U.; Masjuki, H. H. 2010. Energy, exergy and economic analysis of industrial boilers, Energy Policy 38: 2188-2197. http://dx.doi.org/10.1016/j.enpol.2009.11.087 
Scott, J. A.; Ho, W.; Dey, P. K. 2012. A review of multi-criteria decision-making methods for bioenergy systems, Energy 42(1): 146-156. http://dx.doi.org/10.1016/j.energy.2012.03.074

Siemons, R. V. 2002. A development perspective for biomass-fuelled electricity generation technologies: Economic technology assessment in view of sustainability: $\mathrm{PhD}$ thesis. University of Amsterdam.

Sommersacher, P.; Brunner, T.; Obernberger, I. 2012. Fuel indexes: a novel method for the evaluation of relevant combustion properties of new biomass fuels, Energy and Fuels 26: 380-390. http://dx.doi.org/10.1021/ef201282y

Soroudi, A.; Amraee, T. 2013. Decision making under uncertainty in energy systems: state of the art, Renewable and Sustainable Energy Reviews 28: 376-384. http://dx.doi.org/10.1016/j.rser.2013.08.039

Stiegel, G. J.; Maxwell, R. C. 2001. Gasification technologies: the path to clean, affordable energy in the 21st century, Fuel Processing Technology 71(1-3): 79-97. http://dx.doi.org/10.1016/S0378-3820(01)00138-2

Stilger, P. S. 2012. Formulas for choosing the most economically advantageous tender - a comparative study: Master thesis. Utrecht University.

Štreimikiene, D. 2013. Assessment of energy technologies in electricity and transport sectors based on carbon intensity and costs, Technological and Economic Development of Economy 19(4): 606-620. http://dx.doi.org/10.3846/20294913.2013.837113

Tamošaitienè, J.; Gaudutis, E. 2013. Complex assessment of structural systems used for high-rise buildings, Journal of Civil Engineering and Management 19(2): 305-317. http://dx.doi.org/10.3846/13923730.2013.772071

Thrän, D.; Seidenberger, T.; Zeddies, J.; Offermann, R. 2010. Global biomass potentials - resources, drivers and scenario results, Energy for Sustainable Development 14(3): 200-205.

http://dx.doi.org/10.1016/j.esd.2010.07.004

Valentine, J.; Clifton-Brown, J.; Hastings, A.; Robson, P.; Allison, G.; Smith, P. 2012. Food vs. fuel: the use of land for lignocellulosic "next generation" energy crops that minimize competition with primary food production, Global Change Biology. Bioenergy 4(1): 1-19.

http://dx.doi.org/10.1111/j.1757-1707.2011.01111.x

Valmari, T.; Kauppinen, E. I.; Kurkela, J.; Jokiniemi, J. K.; Sfiris, G.; Revitzer, H. 1998. Fly ash formation and deposition during fluidized bed combustion of willow, Journal of Aerosol Science 29(4): 445-459. http://dx.doi.org/10.1016/S0021-8502(97)10021-0

Van Loo, S.; Koppejan, J. 2008. The handbook of biomass combustion and co-firing. Earthscan Publications Ltd. $464 \mathrm{p}$.

Verani, S.; Sperandio, G.; Picchio, R.; Spinelli, R.; Picchi, G. 2008. Field handbook - poplar harvesting International Poplar Commission Thematic Papers. Working Paper IPC/8. FAO, Rome.

Wang, C.; He, B.; Sun, S.; Wu, Y.; Yan, N.; Yan, L.; Pei, X. 2012. Application of a low pressure economizer for waste heat recovery from the exhaust flue gas in a 600 MW power plant, Energy 48:196-202. http://dx.doi.org/10.1016/j.energy.2012.01.045

Yazdani-Chamzini, A.; Fouladgar, M. M.; Zavadskas, E. K.; Haji Moini, S. H. 2013. Selecting the optimal renewable energy using multi criteria decision making, Journal of Business Economics and Management 14(5): 957-978. http://dx.doi.org/10.3846/16111699.2013.766257

Yin, C.; Rosendahl, L. A.; Kaer, S. K. 2008. Grate-firing of biomass for heat and power production, Progress in Energy and Combustion Science 34(6): 725-754. http://dx.doi.org/10.1016/j.pecs.2008.05.002

Zavadskas, E. K.; Vilutiene, T.; Turskis, Z.; Šaparauskas, J. 2014a. Multi-criteria analysis of Projects' performance in construction, Archives of Civil and Mechanical Engineering 14(1): 114-121. http://dx.doi.org/10.1016/j.acme.2013.07.006

Zavadskas, E. K.; Turskis, Z.; Kildienė, S. 2014b. State of art surveys of overviews on MCDM/MADM methods, Technological and Economic Development of Economy 20(1): 165-179.

http://dx.doi.org/10.3846/20294913.2014.892037 


\section{APPENDIX A}

\section{Questionnaire for socio-technical knowledge management}

Prepared in accordance with Raslavičius et al. (2011)

\section{Commune data}

The most important information about the commune was gathered in table below (see Table A-1). Partially, the data has been used to verify data collected during questionnaires survey (see Table A-2).

Table A-1. Commune data sheet

\begin{tabular}{ll}
\hline Commune & Province \\
\hline Type of commune & Rural \\
\hline District & \\
\hline Commune area & $\mathrm{km}^{2}$ \\
\hline Percent of district area & $\%$ \\
\hline Arable land & $\%$ \\
\hline Forests & $\%$ \\
\hline Population of the commune & people \\
\hline Population density & people $/ \mathrm{km}^{2}$ \\
\hline The average per capita income in the commune & $\mathrm{EUR}$ \\
\hline The degree of forest cover area & $\%$ \\
\hline Density of road network & $\mathrm{km} / \mathrm{km}^{2}$ \\
\hline Commune office & tel. \\
& fax \\
\hline
\end{tabular}

Table A-2. Questionnaire form

\begin{tabular}{cl}
\hline No & \multicolumn{1}{c}{ Question } \\
\hline 1 & $\begin{array}{l}\text { If you own a farm, what is the specialty (what is the main source of income } \\
\text { from the activity)? }\end{array}$ \\
\hline 2 & If you own a farm, what is the area in ha? \\
\hline 3 & How do you heat your house? \\
\hline 5 & What type of fuel do you use to heat the house? \\
\hline 6 & $\begin{array}{l}\text { Is the house well heated in winter (do you obtain appropriate temperature } \\
\text { in whole heated area of the house)? }\end{array}$ \\
\hline 7 & What is the heated area of the house? \\
\hline 9 & Did you perform a thermo-modernization? \\
\hline 10 & How much on average do you pay for electricity per month? \\
\hline
\end{tabular}


Continued Table A-2

\begin{tabular}{|c|c|}
\hline No & Question \\
\hline 11 & $\begin{array}{l}\text { Do you cultivate following energy crop: } \\
\text { - Willow: ha, } \\
\text { - Miscanthus: ha, } \\
\text { - Poplar: ha, } \\
\text { - Alder: ha. }\end{array}$ \\
\hline 12 & $\begin{array}{l}\text { What kind of support would you prefer to decide on pro-ecological investment i.e. } \\
\text { biomass boilers, biogas plant, biofuels plant? }\end{array}$ \\
\hline 13 & Would you invest in own source of electric energy? \\
\hline 14 & What kind of heat source is the most interesting for you? \\
\hline 15 & What is the annual cost of heating a house and water and possibly farm buildings? \\
\hline 16 & $\begin{array}{l}\text { Would you be interested in: } \\
\text { - Boiler for biomass, } \\
\text { - Biofuels production, } \\
\text { - Biogas plant. }\end{array}$ \\
\hline 17 & How much would you invest in new (or additional) source of heat to reduce heating costs? \\
\hline 18 & Would you like to invest in order to reduce the environmental pollution? \\
\hline 19 & $\begin{array}{l}\text { What financial support would make you interested in joining the municipal program } \\
\text { supporting investment costs related to biofuels production? }\end{array}$ \\
\hline 20 & Do you use the heat for other purposes than heating the house and water? \\
\hline 21 & Do you know what kind of services are available in your Commune? \\
\hline 22 & Have you ever used advisory services with regard to biomass for energy use? \\
\hline 23 & $\begin{array}{l}\text { What kind of services and support would you like to receive in the Commune } \\
\text { with regard to biomass? }\end{array}$ \\
\hline 24 & Would you be interested in agro-tourism? \\
\hline 25 & $\begin{array}{l}\text { If you would like to own an agro-tourist farm, do you think that energetic use of biomass } \\
\text { would attract tourists? }\end{array}$ \\
\hline 26 & Do you have modern solutions in heating system? \\
\hline 27 & $\begin{array}{l}\text { Are you satisfied with modern solutions with regard to electricity/heat production } \\
\text { and saving? }\end{array}$ \\
\hline
\end{tabular}

Laurencas RASLAVIČIUS is the Vice Dean of the Faculty of Mechanical Engineering and Design at Kaunas University of Technology (KTU MIDF). He holds a PhD in Technological Sciences from KTU. From 2010 until 2014, he occupied a position of innovations engineer for biofuel energy sector at UAB "Axis Technologies" (branch of AB "Axis Industries" - the largest group of companies in Lithuania dealing with industrial and energy sector projects). Between 2001 and 2010, Laurencas worked at the Dept. of Machinery Employment, Dept. of Bioresources, and Dept. of Biotechnologies Engineering at the Lithuanian Institute of Agricultural Engineering (now - Aleksandras Stulginskis University). His work has been focused on liquid and solid biofuels, combined heat and power generation, energy policy, as well as interactions between scientific development, technological change, and private-sector activities in the renewable energy sector. Laurencas participated in national and international bioenergy and renewable energy research projects. From 2011 until 2014, he was invited as an international expert evaluator for 40 research programmes funded by the Romanian Government through the National Council for Scientific Research. Since 2015, Laurencas is a Chief scientific worker / Principal Investigator at KTU MIDF, and Lithuanian expert to the HORIZON 2020 Programme Committee at Brussels officially approved by Ministry of Education and Science of the Republic of Lithuania. 
Brian AZZOPARDI, Prof. Dr Ing. Eur. Ing. is currently a senior academic member of the Malta College of Arts, Science and Technology (MCAST) Institute of Electrical and Electronics Engineering. He have held a number of senior academic and visiting academic and research positions internationally. He holds a PhD from The University of Manchester (UK), BEng with Honours from the University of Malta, two further and higher education certificates, four professional qualifications and a member of five professional bodies. He has over 50 publications and have contributed and participated in several international projects with over $€ 1 \mathrm{M}$ direct budget contribution.

Aleksandr K. KOPEYKA. Professor at Odessa I. I. Mechnikov National University - one of the oldest universities in Ukraine. Research interests: mathematical theory of combustion, combustion modelling, biofuels combustion.

Jonas ŠAPARAUSKAS. Doctor, Associate Professor. Department of Construction Technology and Management. Vilnius Gediminas Technical University. First degree in civil engineering, Vilnius Gediminas Technical University (1997). Master of Science (1999). Doctor (2004). Research visits to Leipzig Higher School of Technology, Economics and Culture (Germany, 2000 and 2001) and Eindhoven University of Technology (The Netherlands, 2002). Researcher in International Project "Inteligent cities" (2004), Member of the EWG-MCDA Working Group within EURO since 2002. Author of more than 15 scientific articles. Research interests: construction technology and organisation, project management, multiple criteria decision making and sustainable urban development. 